\title{
The Significance of Regional Factors for Stimulating Innovativeness of Enterprises in Poland
}

\author{
Alfreda Kamińska \\ Warsaw Management University, Warsaw, Poland \\ alfreda.kaminska@wsm.warszawa.pl \\ Received date: 22 August 2017; Accepted date: 5 December 2017; Published date: 5 June 2018 \\ Academic Editor: Piotr Bębenekj \\ Copyright @ 2018. Alfreda Kamińska. Distributed under Creative Commons CC-BY 4.0
}

\begin{abstract}
The paper aims to identify and systematise meso environmental regional factors stimulating innovativeness of enterprises. Based on analyses of subject literature and own experience, the author distinguishes five main groups of regional conditions of innovativeness: financial (1) and advisory (2) support from local authorities, stimulation of cooperation between economic entities in the given region (3), development and reinforcement of intangible (4) and tangible (5) assets of the region. 27 regional factors were assessed as part of these groups with surveys sent to representative samples of enterprises in Kuyavian-Pomeranian and Silesian voivodeships. Of these five groups, the greatest impact on innovativeness of enterprises comes from the development and reinforcement of tangible and intangible assets of the region, while the surveyed believe financial support for regional entities to be of least importance, with the exception of aid for investment in permanent assets. The research conclusions presented in the article may be helpful for enterprises seeking to grow, business support institutions, and local authorities seeking to develop an effective innovation policy.
\end{abstract}

Keywords: innovativeness, regional conditions of innovativeness.

\section{Introduction}

Innovativeness has had the full attention of business and science and has been perceived as the driving force of development of economies and societies for many years now
(Schumpeter 1961), but the innovativeness level of Polish economy and enterprises is still unsatisfactory. In global and European rankings, Poland scores low on innovativeness and like other Visegrád countries (Czech Republic, Hungary,

Cite this Article as: Alfreda Kamińska (2018)," The Significance of Regional Factors for Stimulating Innovativeness of Enterprises in Poland", Journal of Innovation \& Business Best Practice, Vol. 2018 (2018), Article ID 538731, DOI: 10.5171/2018.538731 
Slovakia) is listed among "moderate innovators" (European Innovation

Scoreboard, 2017).

Europe's regions are grouped into four innovation performance groups according to their performance on the Regional Innovation Index relative to that of the EU:

- "innovation leaders" - 53 regions with performance more than $20 \%$ above the EU average.

- "strong innovators" - 60 regions with performance between $90 \%$ and $120 \%$ of the EU average.

- "moderate innovators" - 85 regions with performance between $50 \%$ and $90 \%$ of the EU average.

- "modest innovators" - 22 regions with performance below $50 \%$ of the EU average.

Poland includes 16 regions: Mazowieckie, the capital region, is the most innovative region and the only "moderate innovator"; seven regions are "moderate" and nine regions are "modest innovators" (Regional Innovation Scoreboard, 2017). One of the causes of low innovativeness of regions is the low innovativeness of enterprises. Research conducted as part of the Community Innovation Survey (CIS) points to a persistent low level of innovativeness in Polish enterprises (EIS, 2017).

Within this paper, innovativeness of enterprises means the capacity of companies to pursue innovation in order to introduce new products, processes, marketing ideas and organisational concepts (Hult, Hurley \& Knight, 2004; OECD \& Eurostat, 2005).

The matter of conditions of innovativeness of enterprises is one of the most frequently analysed issues in the study of innovativeness, however, the literature on it usually only considers microeconomic and macroeconomic circumstances. Meanwhile, we can see at present that the mesoeconomics context, understood as a collection of factors that come into play at a regional level and create conditions that are more or less conducive to innovative activity by organisations within a given region (voivodeship in our case), is becoming ever more important.

The interdisciplinary nature of research into regional impact on innovativeness of enterprises generates interest from geographers, economists, management researchers, sociologists. The literature mostly features the regional context of conditions of innovativeness as seen from the level of a city, an urban area, or a metropolis, that is, from a local level. Urban centres, particularly metropolises, are considered the most important locations for innovation, as they offer a large potential for it in a small area. Polish and global literature has relatively few overviews of the regional context of the processes of innovation (Porter, 2001; Nowakowska, 2009, 2011; Jewtuchowicz, 2005; Bellman et al., 2013). In particular, many works deal with the impact of innovativeness on economic development within a given region and analyse regional innovativeness systems (Strahl, 2010; Stawasz, 2006; Świadek, 2007, 2011 and others).

This paper considers the impact of regional conditions on innovativeness of enterprises in Poland As the Oslo Manual notes, "identifying the main characteristics and factors that promote innovation activity and the development of specific sectors at regional level can help in understanding innovation processes and be valuable for the elaboration of policy" (OECD \& Eurostat, 2005).

The chief purpose of the paper is to attempt to answer the following questions: how large is the impact of regional conditions on innovativeness of enterprises? and what is the relationship between innovativeness in enterprises and the assessment of the importance of regional factors? The main goal 
is the attempt to systematise and determine the role of regional factors that impact innovativeness in enterprises.

\section{Regional conditions of innovativeness of enterprises: overview of literature}

There are a great number of diverse types of factors impacting innovativeness of enterprises. The literature on it usually divides them into two major groups: endogenous and exogenous. Endogenous factors are a result of material and nonmaterial resources available to the company, while exogenous factors are related to the broadly-understood environment - which is a part of the micro environment, meso environment, and macro environment, as well as the global environment. At a time of increasing globalisation, the role of regions is, contrary to expectations, increasing, while the economists outline a new and independent field of study called the mesoeconomics (Gorynia, 2008), which researches economic phenomena that occur at the level of sections, branches, economic sectors and regions. This paper analyses meso environmental factors in a regional context and a region is understood to be a given voivodeship.

One of the first scholars to notice the impact of outside environment on enterprise creation and innovativeness of enterprises was Aydalot (1986), who declared in the 1980s that the source of innovation is the environment (innovative milieu) that the company operates in. As Guinet (1995) and other scholars of innovation accurately pointed out, innovative activity is interactive, a result of relationships within the enterprises and between it and outside agents such as clients, suppliers, researches, development units, local authorities, financial institutions and any and all other supporting companies.

Sternberg and Arndt (2001) believed that the most important regional determinants of innovativeness of enterprises include local availability of qualified personnel, research and development facilities, technology transfer, appropriate economic structures, and soft factors (facilities etc.), institutional support, and innovative policy factors in the macro environment and meso environment (including support for operations growth and $R \& D$ cooperation). The list of regional factors impacting innovativeness of enterprises was expanded with local and central government initiatives, macroeconomic trends, financial support, education, economic structure, knowledge and technology transfer, infrastructure, values, and norms (Sternberg \& Litzenberg, 2004).

Porter (2001) listed four main groups of regional determinants: 1) factor (input) conditions: high quality specialised inputs such as human and capital resources, knowledge and technology, physical, administrative, and information infrastructure, natural resources; 2) demand conditions: sophisticated and demanding regional customers, local demand in specialised segments; 3) related and supporting industries: access to capable, locally based suppliers and firms in related fields, inter-industry cooperation (clusters); 4) context for firm strategy and rivalry: local context that encourages investment and sustained upgrading (including protection of intellectual property), competition among locally based rivals.

Sosnowska, Poznańska, Łobejko, Brdulak, Chinowska (2003) pointed out the factors resulting from the location of the enterprise, such as the economic situation of the region, market access, collaborative connections to other firms, cooperation with local authorities, contacts with higher education facilities and R\&D facilities, infrastructure layout, environmental protection restrictions.

Innovativeness of enterprises is shaped by regional politics, actions of institutions from the business environment, and technological, social, and economic structure of the region (Jasiński \& Wiatrak, 2010). 
Meanwhile, Broekel and Brenner (2011) researched an astounding 70 variables describing the socio-economic situation of a region, divided into 12 groups of factors influencing innovativeness in a region.

Kosała and Wach (2011) have projected the innovative potential of a region based on a number of metrics, including research and development spending and its sources, research and science workers per 1000 employed, gross value of research tools, the number of R\&D units, reported inventions and patents granted, foreign trade balance in cutting edge technology products, share of innovative enterprises in the overall number of companies.

In Nowakowska's (2011) view, innovative processes are determined by the potential of the R\&D sector, the academic potential, the activity of institutions supporting the innovation processes, the technology transfer and the presence of clusters.

Meanwhile, Świadek (2011) has analysed the impact of the following factors: the distance from urban areas and relations with the competition, suppliers, buyers, the number of suppliers and buyers, interactions between and within sectors, access to capital, employee skills. Bellmann, Crimmann, Evers and Hujer (2013) have pointed out the importance of human resources - namely, STEM graduates as well as the distance from research and technology centres and tertiary education facilities, and the unemployment rate in the region.

The review of the subject literature and own experiences and observations give reason to name five main, codependent groups of regional conditions, which have been assigned 27 factors determining innovativeness of enterprises. They are listed in Table 3.

Inasmuch as the list cannot be considered complete or exhaustive of the all the possibilities of a region's impact on innovativeness in enterprises, it does provide a toolkit for the identification of the most important conditions and for an assessment of the extent of their influence.

\section{Research Methodology}

The aim of the research was to determine the impact regional conditions of innovativeness of enterprises have and the links between the level of innovativeness in companies and the assessment of the importance of those factors. The research was conducted in Poland, in enterprises located in two Voivodeships of different innovativeness level and different economic situation, namely, Silesian and Kuyavian-Pomeranian.

Silesian Voivodeship was ranked fourth in the country in innovativeness, while KuyavianPomeranian came fourteenth (RIS 2017). RIS values position the latter in the weakest EU regional innovation bracket (i.e. regional modest innovators), while Silesian is ranked among regional moderate innovators. In terms of economic development measured by GDP per capita, the Silesian Voivodeship is fourth in the country, while Kuyavian-Pomeranian is tenth (GUS, 2016).

Empirical research has been performed by survey augmented with extended interviews with the management of the enterprises. The research tool for the survey stage was a questionnaire prepared by the author, while the research was conducted by the Centrum Badania Opinii Społecznej (Centre for Public Opinion Research, CBOS). The interviews were conducted according to the CATI (Computer Assisted Telephone Interview) method - a quantitative research method. Like in Eurostat research, company size was accepted as a criterion for assigning the companies in question to groups (of small, medium, or large enterprises). The sample was selected according to the recommendations of the Oslo Manual "that the stratification of random sample innovation surveys should be based on the size and principal activity of the units" (OECD \& 
Eurostat, 2005). Ultimately, empirical research was conducted on a sample that was representative both in terms of size (due to the number of employees) and in terms of sectional activity (as per the Polish Activity Classification - PKD), which included 265 small, medium, and large enterprises in the Kuyavian-Pomeranian Voivodeship and 259 small, medium, and large enterprises in the Silesian Voivodeship. The structure of enterprises analysed as part of the research is proportional to the structure of all enterprises in the regions (Table 1). The number of research samples and their structure allow an assumption that the conclusions drawn from the work presented in the paper on the impact and the importance of regional conditions on innovativeness in enterprises are very likely to be representative for the entire populations of enterprises in the Kuyavian-Pomeranian and Silesian Voivodeships, aside from any micro-scale units.

Table 1: Structure of surveyed companies (in \%)

\begin{tabular}{|l|c|c|c|c|c|c|c|}
\hline \multirow{2}{*}{ Voivodeship } & \multicolumn{3}{|c|}{ Number of employees } & \multicolumn{4}{|c|}{ Activity type } \\
\cline { 2 - 8 } & $10-49$ & $\begin{array}{c}50- \\
249\end{array}$ & $\begin{array}{c}250 \text { and } \\
\text { more }\end{array}$ & Manufacturing & Services & Commerce & Mixed \\
\hline $\begin{array}{l}\text { Kuyavian-Pomeranian } \\
(\mathrm{N}=265)\end{array}$ & 84.0 & 14.0 & 2.1 & 42.7 & 28.8 & 15.8 & 12.8 \\
\hline Silesian (N=259) & 85.5 & 12.3 & 2.2 & 41.7 & 32.4 & 22.4 & 3.4 \\
\hline
\end{tabular}

Source: own research

The general research was performed between October and December 2016. When preparing the survey questionnaire, the author drew from subject matter literature and her own experience from years of work at various enterprises. Moreover, in order to better understand the problems that fell within the scope of the research and to capture the elements most important to the entrepreneurs and the economy, she interviewed managers about the regional conditions of innovativeness of enterprises. As per procedure for surveys, it started with a pilot study, which allowed for a test of the research tools, clarification of any ambiguities and an assessment of the time needed to conduct the survey.

\section{Results and Discussion}

\section{Assessment of Innovativeness in Surveyed Enterprises}

In order to achieve the main goal of determining the importance of regional conditions of innovativeness in enterprises and their influence its level, it was necessary to assess the level of innovativeness in the surveyed subjects in both Voivodeships.

Based on the subject literature quoted earlier, several crucial markers of the innovativeness process in enterprises were named. These included: the number of innovativeness in product, in process, in marketing, and in organisation over the past three full years (i.e. 2013, 2014, and 2015), the degree of novelty of the innovation (on a five-step scale: novel for the enterprise, locally novel, regionally novel, novel for the country, novel internationally), and a subjective assessment of the innovativeness level of the enterprise by the survey respondent.

Depending on the number and novelty of the innovations introduced between 2013 and 2015 , every enterprise was assigned to one of six groups based on their level of innovativeness: "very high," "high," "average," "low," "very low" or "non-innovative." To measure the appropriateness of the accepted criteria for the assessment, the results were 
cross-referenced with the resulting enterprise structure and the self-assessment of the level of innovativeness of enterprises performed by the respondents.

Table 2 presents the innovativeness structure of the entire surveyed sample. The analysis shows that both voivodeships have a similar innovativeness structure in enterprises. Noninnovative companies, which had not introduced any innovation in product, process, marketing, or organisation in the period surveyed, represent more than $50 \%$ of the firms in the survey. Around one in five enterprises $(20.1 \%, 21.2 \%) \quad$ introduced between one and three enterprise-level innovations, putting them in the group of companies with a very low innovativeness level. Higher levels of innovativeness show insignificant differences between the two voivodeships. The Silesian Voivodeship has a 2.1 percentage point lower share of medium innovativeness firms (4-10 company, local, regional innovations, 1-10 national innovations) and a 1.9 percentage point higher share of very high innovativeness firms (more than 10 national or sub-national innovations). It also has a 5.6 percentage point higher share of low innovativeness firms (1-3 local or regional innovations). The very high percentage of companies that had introduced no innovations in the researched timespan and of those at a very low level of innovativeness testifies to a low general level of innovativeness in enterprises in both voivodeships in question.

Table 2: Innovativeness structure of companies in the research sample (in \%)

\begin{tabular}{|l|c|c|}
\hline Innovativeness level & $\begin{array}{c}\text { Kuyavian-Pomeranian Voivodeship } \\
(\mathrm{N}=265)\end{array}$ & $\begin{array}{c}\text { Silesian Voivodeship } \\
(\mathrm{N}=259)\end{array}$ \\
\hline Non-innovative & 58.8 & 56.1 \\
\hline Very low & 20.1 & 21.2 \\
\hline Low & 8.3 & 13.9 \\
\hline Average & 9.4 & 7.3 \\
\hline High and very high & 3.4 & 1.5 \\
\hline
\end{tabular}

Source: own research

\section{Impact of Regional Conditions on Innovativeness of Enterprises}

To determine the importance and the impact of regional conditions on innovativeness of enterprises, the respondents were asked to evaluate 27 regional variables divided into five groups. They were asked to evaluate their importance on a five-step scale: very large (5), large (4), average (3), small (2), unimportant (1). These factors were then ranked based on the average evaluation score, as shown in Table 3. 
Table 3: Impact of regional conditions on innovativeness in enterprises - average scores

\begin{tabular}{|c|c|c|}
\hline & $\begin{array}{l}\text { Kuyavian- } \\
\text { Pomeranian } \\
\text { Voivodeship }\end{array}$ & $\begin{array}{l}\text { Silesian } \\
\text { Voivodeship }\end{array}$ \\
\hline \multicolumn{3}{|c|}{ FINANCIAL SUPPORT OF REGIONAL AGENTS BY LOCAL GOVERNMENT } \\
\hline Financial aid for investment in permanent assets & 3,28 & 3,22 \\
\hline $\begin{array}{l}\text { Subsidising and development of financial institutions, } \\
\text { facilitating access of enterprises to capital }\end{array}$ & 2,95 & 2,93 \\
\hline $\begin{array}{l}\text { Financial aid for autonomous R\&D activities in } \\
\text { enterprises }\end{array}$ & 2,72 & 2,65 \\
\hline $\begin{array}{l}\text { Financial aid for purchase of consulting services, } \\
\text { licenses, patents and so forth }\end{array}$ & 2,71 & 2,73 \\
\hline $\begin{array}{l}\text { Financial aid for cooperation with scientific research } \\
\text { institutions }\end{array}$ & 2,63 & 2,72 \\
\hline $\begin{array}{l}\text { Financing for creation and development of special } \\
\text { economic zones }\end{array}$ & 2,50 & 2,52 \\
\hline $\begin{array}{l}\text { Financial support for creation and development of } \\
\text { scientific research institutions and innovation centres }\end{array}$ & 2,35 & 2,29 \\
\hline \multicolumn{3}{|c|}{$\begin{array}{l}\text { ORGANISATIONAL AND ADVISORY SUPPORT OF REGIONAL ECONOMIC AGENTS BY LOCAL } \\
\text { GOVERNMENT }\end{array}$} \\
\hline $\begin{array}{l}\text { Organisational and advisory aid for enterprises } \\
\text { (including them in projects, organising conferences } \\
\text { and training) }\end{array}$ & 3,36 & 3,34 \\
\hline Engaging innovation centres in pro-innovative activity & 2,87 & 2,79 \\
\hline $\begin{array}{l}\text { Public procurement of innovative goods and services by } \\
\text { local authorities }\end{array}$ & 2,64 & 2,48 \\
\hline Investment in public-private partnership & 2,43 & 2,30 \\
\hline \multicolumn{3}{|c|}{ PROMOTING COOPERATION BETWEEN REGIONAL AGENTS BY LOCAL GOVERNMENT } \\
\hline $\begin{array}{l}\text { Price of services offered by institutions supporting } \\
\text { innovation }\end{array}$ & 3,53 & 3,66 \\
\hline $\begin{array}{l}\text { Local government aid for interregional and international } \\
\text { cooperation (organising fairs, meetings, study visits etc.) }\end{array}$ & 3,34 & 3,45 \\
\hline $\begin{array}{l}\text { Facilitating cooperation with training and consultancy } \\
\text { centres }\end{array}$ & 3,25 & 3,33 \\
\hline $\begin{array}{l}\text { Tailoring the offer of business environment institutions } \\
\text { to the needs of companies }\end{array}$ & 3,00 & 3,05 \\
\hline Location of institutions supporting innovativeness & 2,98 & 3,08 \\
\hline $\begin{array}{l}\text { Facilitating cooperation between enterprises and } \\
\text { science }\end{array}$ & 2,87 & 3,03 \\
\hline $\begin{array}{l}\text { Facilitating cooperation between enterprises and } \\
\text { innovation centres }\end{array}$ & 2,86 & 2,99 \\
\hline $\begin{array}{l}\text { Facilitating access to services of research institutions } \\
\text { and laboratories }\end{array}$ & 2,76 & 2,82 \\
\hline $\begin{array}{l}\text { Local government aid in the functioning of connection } \\
\text { networks between enterprises and pro-innovation } \\
\text { institutions, including clusters }\end{array}$ & 2,71 & 2,52 \\
\hline
\end{tabular}




\begin{tabular}{|l|c|l|}
\hline \multicolumn{3}{|c|}{ CREATION AND AUGMENTATION OF OTHER NON-MATERIAL RESOURCES OF THE REGION } \\
\hline $\begin{array}{l}\text { Local government aid for development of human } \\
\text { capital }\end{array}$ & 3,45 & 3,60 \\
\hline $\begin{array}{l}\text { Creation of knowledge centres within the region and } \\
\text { providing free access to market analyses, databases, } \\
\text { information sources etc. }\end{array}$ & 3,24 & 3,38 \\
\hline $\begin{array}{l}\text { Promoting entrepreneurial and innovative attitudes in } \\
\text { the region }\end{array}$ & 3,22 & 3,29 \\
\hline $\begin{array}{l}\text { Increasing the capability of public administration to } \\
\text { handle innovation and improvement of functioning of } \\
\text { local administration }\end{array}$ & 3,01 & 3,23 \\
\hline \multicolumn{1}{|c|}{ CREATION AND AUGMENTATION OF OTHER MATERIAL RESOURCES OF THE REGION } \\
\hline Development of transport infrastructure & 3,88 & 3,91 \\
\hline $\begin{array}{l}\text { Development of communications and computing } \\
\text { infrastructure }\end{array}$ & 3,65 & 3,71 \\
\hline $\begin{array}{l}\text { Making the region more attractive for foreign } \\
\text { investment }\end{array}$ & 3,18 & 3,40 \\
\hline
\end{tabular}

Source: own research

Financial conditions are an important group of factors determining innovative activity of enterprises. Research shows that financial limitations are one of the most important barriers to introducing innovation (Kamińska 2016). According to the answers from both voivodeships, the most important financial factor for the realisation of innovative processes is financial aid for investment in permanent assets. This factor was given an average score of 3.28 in the Kuyavian-Pomeranian Voivodeship and 3.22 in the Silesian Voivodeship. The second most important factor - per the answers - is the financing and development of financial institutions (including lenders and guarantors, high-risk capital) and facilitating access to capital. This factor was rated at 2.95 and 2.93, respectively - a lot lower than financing enterprises.

The assessment of the following factors shows little difference between the voivodeships. The Kuyavian-Pomeranian Voivodeship respondents place financial aid for autonomous in-house R\&D to be the third most important condition (average grade of 2.72), while those in Silesian greatly prefer cooperating on R\&D with outside institutions (same grade). The surveyed find the financial aid for the purchase of consulting services, licenses, patents to be less important, as it was rated respectively at 2.71 and 2.73 . Respondents in both voivodeships are largely in agreement on the least important factors of this group. They put financing the creation and development of special economic zones as second to last, with an impact score of 2.50 and 2.52, while - in their opinion - the least important boost for innovativeness of enterprises is financial support for the development and creation of scientific research institutions and innovation centres $(2.35,2.29)$.

Analysis shows a notable correlation in the Kuyavian-Pomeranian Voivodeship between financial factors and innovativeness level of specific enterprises when evaluating the importance of capital aid for permanent investments. This type of financial aid is more important for companies at a higher level of innovativeness, with Spearman's rank correlation coefficient $\left(\mathrm{r}_{\mathrm{S}}\right)$ of 0.216 at probability value $(p)$ of 0.001 . Meanwhile, according to more innovative enterprises, subsidising and development of financial institutions such as loan funds, which is understandable, as these companies tend to have a better access to bank loans. In the Silesian Voivodeship, important correlations 
between the innovativeness level and the assessment of importance of financial factors are more frequent. Enterprises with a higher innovativeness level placed more importance on six out of seven surveyed financial factors, with the correlations being absent only on the subject of subsidies for special economic zones.

The respondents from both voivodeships have returned an identical ranking of factors in the organisational and advisory support group. They consider direct aid for enterprises, including enlisting them in innovative undertakings and passing on necessary knowledge and information in conferences and training seminars, to be the most important element for increasing innovativeness, with a rating average of 3.36 in Kuyavian-Pomeranian and 3.34 in Silesian. Many enterprises believe that a broad engagement of innovation centres in proinnovative tasks translates into a higher level of innovativeness in firms, and therefore they place that factor in second place, with a respective rating average of 2.87 and 2.79 . According to the respondents, public bids from local government have little impact on innovativeness, thus the average rates of 2.64 and 2.48. The last of the surveyed factors development of investments in public-private partnership (PPP) - has been listed as the least relevant (2.43 and 2.30), which is appropriate considering the current situation in Poland in this regard, with one in five answers stating that is has no impact on innovativeness of enterprises. It is not a surprise that organisational and advisory aid for enterprises, including bringing them onboard in innovative projects and providing training, has been rated the highest. The dynamics of the changes in the current business environment imply the need for a constant refreshing of knowledge and new, up-to-date information, and research indicates that the entrepreneurs are aware of this fact.

The assessment of the importance of organisation and advisory factors varies based on the level of innovativeness of a given enterprise. Those at a higher level of innovativeness see involving innovation centres with pro-innovative activities and local government procurement of innovative products to be more important. This occurs in both voivodeships.

As for the promoting of cooperation of regional agents group, the respondents from both voivodeships decided that the three most important factors for increasing innovation were: the price level of services rendered by innovation-supporting institutions (ratings in voivodeships respectively $3.53,3.66$ ), local government aid for interregional and international cooperation of enterprises $(3.34,3.45)$ and facilitating access to training and consulting support $(3.25,3.33)$. The results of a lot of research conducted in Poland indicate that a high price of services from business environment institutions is one of the principal barriers to innovativeness and development of enterprises (Kamińska, 2016a, 2016b).

Today, when costs are constantly being cut and price is seen as a major element of competitive advantage, the price factor is unsurprisingly rated highly. What is interesting, however, is that the entrepreneurs surveyed - even though the range of their activity is currently very limited (mostly to local and regional market), think in the long term and want to find new markets in other regions and countries, which is why organising fairs, study visits, and other meetings that contribute to establishing new contacts is so important to them. Noticing the need for training and new knowledge (thirdhighest-rated factor in the group) is also a good trait of the surveyed managers.

The other factors are ranked similarly in both voivodeships - the entrepreneurs see similar value in facilitating collaboration with the science sector and innovation centres. In the last place comes the help of local governments for clusters and other forms of cooperation. 
When considering the differences in evaluation of different factors in this group and their correlation with the innovativeness level in enterprises, it appears that in both voivodeships companies with a higher level of innovativeness place a much greater focus on facilitating access to research institutions $\left(\mathrm{r}_{\mathrm{s}}\right.$ in the Kuyavian-Pomeranian of 0,307 with $p$ below 0,0005, in Silesian, 0,299 with $p$ below 0,0005).

Another investigated group of regional conditions were the various activities related to the creation and augmentation of nonmaterial resources of the region. The analysis of the answers from both voivodeships points that out of this group, the largest importance is attributed to local government actions for the development of human capital, rated in both voivodeships at 3.45 and 3.60 , respectively. That these activities placed this high testifies to the entrepreneurs' understanding that knowledge and skills of employees are the key to inspiring innovativeness. Companies are aware of the need for broad knowledge and information in order to introduce innovation, and of their own lacks in that regard, which is why they rank the need for knowledge centres in their regions and free access to any and all analyses and data helpful for innovative undertakings as the second most important factor in this group. In the view of the respondents, promoting entrepreneurial and innovative attitudes in a region is more important than increasing the capabilities of public administration in innovation and improving its functioning. It is worth highlighting that projects accomplished as part of efforts to promote innovativeness and entrepreneurship are not costly and their introduction frequently depends solely on the will and activity of the local authorities. Of note are the high average notes of the factors in this group (average above 3.0) compared to other sets of conditions.

Referencing the evaluations with the innovativeness level of enterprises brings important conclusions. It appears that the relatively high rating of these factors is independent of the actual level of innovativeness a given company exhibits.

According to the answers, all the listed material assets of a region are very important to innovativeness of enterprises. In this section, the highest rank went to the development of transport infrastructure, rated, respectively, at 3.88 and 3.91. Second place went to the development of communications and computing infrastructure, where average grades were also high, standing at 3.65 and 3.71 . Therefore, the entrepreneurs believe that the development of innovative economic activity is very tightly connected to transport and information network, which allow for either face-to-face or computer-mediated communication with other agents, including suppliers and clients. Respondents from both voivodeships give a high mark to actions intended to make a region more attractive to foreign investments (average ratings 3.18 and 3.40). This shows they are not afraid of competition from abroad, while remaining aware that foreign investment may contribute to the development of their enterprises and regions. We also do not notice any correlation between the assessment of specific factors and the level of innovativeness in a given company.

\section{Conclusions}

The changing nature of the business environment and the low level of innovativeness in Polish enterprises give cause for systematic research to identify the factors that determine the innovativeness of enterprises with a view to regional factors. The results produced by the research are congruent with the findings of RIS 2017 and point to a low level of innovativeness of enterprises in the regions in question. The research presented here has identified the relatively most important factors influencing innovativeness in each of five groups of region-level conditions: 
1. In the group of factors related to financial support from the local government, both the respondents from the Kuyavian-Pomeranian Voivodeship and from the Silesian Voivodeship declared that the most important element is financial aid for investment in permanent assets as well as subsidising and development of financial institutions so as to facilitate access of enterprises to capital.

2. As for the local government organisational and the advisory support, the most important factor was involving the enterprises in projects, organising conferences and training, and engaging innovation centres with proinnovative activity. The assessment of the two most important factors in this group varies greatly, as enterprises in general prefer aid that is offered directly to them and not to other institutions. For this reason, involving companies in innovative projects directly and allowing them to obtain necessary knowledge and information is considered by the survey respondents to be the most important condition of innovativeness.

3. Among the factors serving to inspire cooperation between various subjects in a region, the most important ones included the prices of services rendered by institutions supporting innovativeness and local government aid for companies in interregional and international cooperation.

4. Among the factors creating and reinforcing non-material resources of a region, involving the local government in developing the human capital (by handing out grants, stipends, organising training, promoting talent, tailoring education to fit the needs of the region and so forth) was deemed the most important. Another factor of great relevance of this group is the creation of knowledge centres in regions and the free access to market analyses, databases, and information sources necessary to bring about innovation processes.

5. In both voivodeships, the development of transport and telecommunications infrastructure was named the most important factors in the creation and augmentation of a region's material resources group. Of note are high ratings given to this group of factors underpinning effective operations of enterprises.

When comparing the importance of the five groups of regional conditions, the entrepreneurs place the creation of material and non-material resources in the first place. In turn, they attribute the least importance to financial support of regional agents, aside from subsidising investment in permanent assets of enterprises. Considering the high importance placed on the financial factors on the micro- and macroeconomic level, it is a piece of information of both interest and the importance for local governments who seek to conduct a policy of supporting innovativeness. At the same time, none of the factors reviewed in the survey received an average note of less than 2.0, which would mean that it is of very little importance.

In both voivodeships, the more innovative companies find the following factors more important than the less innovative companies do:

- financial aid for investment in permanent assets,

- financial aid for cooperation with scientific research institutions,

- Subsidising and the development of financial institutions, facilitating access of enterprises to capital,

- Engaging innovation centres in proinnovative activity,

- Public procurement of innovative goods and services by local authorities,

- Facilitating access to services of research institutions and laboratories, 
- Facilitating cooperation with training and the consultancy centres.

Therefore, more innovative companies are more open to their environment and willing to cooperate with it. They appreciate the need to use knowledge and services of research, training, and consulting institutions. These correlations are present in both voivodeships. Although the two regions differ in their level of social and economic development, only in 3 out of 27 cases do their assessments conflict, pointing to a more or less universal nature of the factors in question and the need to take them into account while designing and pursuing regional innovativeness policies, while at the same time noting the specifics of any given area.

The research has allowed a systematisation of the most important regional factors and an assessment of their impact on innovativeness in the regions in question. It is, however, limited by the subjective nature of the responses when evaluating the importance of regional conditions of innovativeness of enterprises, although attempts were made to minimise any potential errors in replies by a number of measures, including selecting respondents among the management. The impossibility of taking into account all regional factors and the overlap of factors from various levels of business environment as well as applying a scale for the level of innovativeness of given enterprises are the further limiting factors of the study. An important research question for the future is the diagnosis of the impact of regional conditions on the effectiveness of the companies.

\section{References}

1. Aydalot, Ph. (1986), 'L'aptitude des milieux locaux à promouvoir l'innovation, Technologie nouvelle et ruptures régionales', Economica, Paris [in:] Nowakowska, A. (ed.) (2009), Budowanie zdolności innowacyjnych regionów, Wydawnictwo Uniwersytetu Łódzkiego, Łódź.

2.Bellmann, L., Crimmann, A., Evers, K. and Hujer, R. (2013), 'Regional Determinants of Establishments' Innovation Activities: A Multi-Level Approach', IZA DP No. 7572. [Online], [Retrieved May 18, 2017], https://www.econstor.eu/bitstream/10419/ 89797/1/dp7572.pdf.

3. Broekel, T. and Brenner, T. (2011), 'Regional factors and innovativeness: an empirical analysis of four German industries', The Annals of Regional Science, 47 (1), 169194.

4.European Commission (2017), European Innovation Scoreboard 2017, [Online], [Retrieved July 28, 2017], http://ec.europa.eu/DocsRoom/documents/ $\underline{24829}$.

5. European Commission (2017), Regional Innovation Scoreboard 2017, [Online], [Retrieved July 28, 2017], http://ec.europa.eu/docsroom/documents/ 23881.

6. Gorynia, M. (2007), Studia nad transformacją i internacjonalizacją gospodarki polskiej, Wydawnictwo Difin, Warszawa.

7. Guinet, J. (1995), National Systems for Financing Innovation, OECD, Paris.

8. GUS (2016), Wstępne szacunki produktu krajowego brutto według województw $\mathrm{w}$ 2015 r., Urząd Statystyczny w Katowicach, Warszawa 30.12.2016 r. [Online], [Retrieved May 28, 2017], www.stat.gov.pl.

9. Hult, G.T.M., Hurley, R.F. and Knight, G.A. (2004), 'Innovativeness: It's antecedents and impact on business performance', Industrial Marketing Management, 33(5), 429-438.

10. Jasiński, A.H. (ed.) (2010), Innowacyjność polskiej gospodarki w okresie transformacji, Wydawnictwo Naukowe 
Wydziału Zarządzania Uniwersytetu Warszawskiego, Warszawa.

11. Kamińska, A. (2016a), 'Uwarunkowania aktywności innowacyjnej przedsiębiorstw przemysłowych', Nauki o Zarządzaniu, 1(26), 77-90, [Online], [Retrieved May 8, 2017], https://www.ceeol.com/search/articledetail?id=343201.

12. Kamińska, A. (2016b), 'Conditions of Innovativeness Growth of Enterprises in Poland', Central European Review of Economics \& Finance, 14(4), 25-34, [Online], [Retrieved May 8, 2017], http://yadda.icm.edu.pl/yadda/element/bw meta1.element.ekon-element$\underline{000171452787 .}$.

13. Kamińska, A. (2017), Uwarunkowania regionalne innowacyjności przedsiębiorstw w Polsce, Wydawnictwo CeDeWu, Warszawa.

14. Kosała, M., Wach, K. (2011), 'Regionalne determinanty rozwoju innowacyjności przedsiębiorstw', Zeszyty Naukowe Uniwersytetu Ekonomicznego $w$ Krakowie, 866, 19-36.

15. Nowakowska, A. (2011), Regionalny wymiar procesów innowacji, Wydawnictwo Uniwersytetu Łódzkiego, Łódź.

16. OECD, Eurostat (2005), Oslo Manual 2005. Guidelines for Collecting and Interpreting Innovation Data, Third Edition, Paris. [Online], [Retrieved May 8, 2017], http://www.oecd.org/science/inno/236758 $\underline{0 . p d f}$.

17. Porter, M.E. (2001), 'Research Triangle. Clusters of Innovation Initiative.',
Harvard University, Washington. [Online], [Retrieved May 18, 2017], http://www.hbs.edu/faculty/Publication $\% 2$ 0Files/COI ResearchTriangle cfb27f081329-4637-b6b0-d185d9f418ee.pdf.

18. Schumpeter, J.A. (1961), The theory of economic development: An inquiry into profits, capital, credit, interest and the business cycle, USA, Harvard University Press.

19. Sosnowska, A., Poznańska, K., Łobejko, S., Brdulak, J. and Chinowska, K. (2003), Systemy wspierania innowacji i transferu technologii $w$ krajach Unii Europejskiej i w Polsce, PARP, Warszawa.

20. Sternberg, R. and Arndt O. (2001), 'Source The Firm or the Region: What Determines the Innovation Behavior of European Firms?', Economic Geography, 77(4), 364-382.

21. Sternberg, R. and Litzenberg, T. (2004), Regional Clusters in Germany Their Geography and Their Relevance for Entrepreneurship Activities', European Planning Studies, 12(6), 767-790, [Online], [Retrieved May 8, 2017], http://www.tandfonline.com/doi/abs/10.10 80/0965431042000251855.

22. Strahl, D. (ed.), (2010), Innowacyjność europejskiej przestrzeni regionalnej a dynamika rozwoju gospodarczego, Wydawnictwo Uniwersytetu Ekonomicznego we Wrocławiu, Wrocław.

23. Świadek, A. (2011), Regionalne systemy innowacji w Polsce, Wydawnictwo Difin, Warszawa. 